
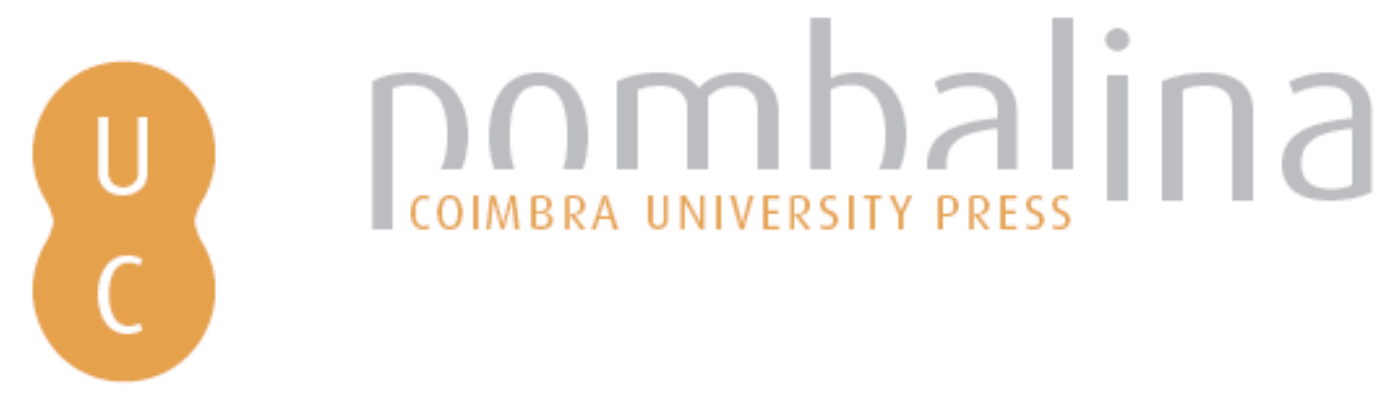

\title{
Educação em Esparta e em Atenas: dois métodos e dois paradigmas
}

Autor(es): $\quad$ Ferreira, José Ribeiro

Publicado por: Centro de Estudos Clássicos e Humanísticos; Imprensa da Universidade

URL

persistente: URI:http://hdl.handle.net/10316.2/31541

DOI: $\quad$ DOI:http://dx.doi.org/10.14195/978-989-8281-23-4_1

Accessed : $\quad$ 26-Apr-2023 12:55:42

A navegação consulta e descarregamento dos títulos inseridos nas Bibliotecas Digitais UC Digitalis, UC Pombalina e UC Impactum, pressupõem a aceitação plena e sem reservas dos Termos e Condições de Uso destas Bibliotecas Digitais, disponíveis em https://digitalis.uc.pt/pt-pt/termos.

Conforme exposto nos referidos Termos e Condições de Uso, o descarregamento de títulos de acesso restrito requer uma licença válida de autorização devendo o utilizador aceder ao(s) documento(s) a partir de um endereço de IP da instituição detentora da supramencionada licença.

Ao utilizador é apenas permitido o descarregamento para uso pessoal, pelo que o emprego do(s) título(s) descarregado(s) para outro fim, designadamente comercial, carece de autorização do respetivo autor ou editor da obra.

Na medida em que todas as obras da UC Digitalis se encontram protegidas pelo Código do Direito de Autor e Direitos Conexos e demais legislação aplicável, toda a cópia, parcial ou total, deste documento, nos casos em que é legalmente admitida, deverá conter ou fazer-se acompanhar por este aviso.

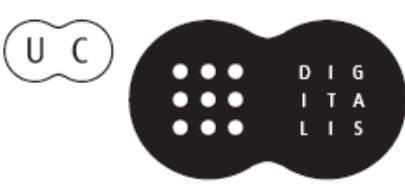


Colecção Autores Gregos e Latinos Série ENSAIOS

\section{Delfim Ferreira Leão José Ribeiro Ferreira Maria do Céu Fialho}

CIDADANIA E PAIDEIA

Na Grécia Antiga 


\title{
EducaÇáo em Esparta e em Atenas DOIS MÉTODOS E DOIS PARADIGMAS
}

\author{
José Ribeiro Ferreira
}


Esparta e Atenas tinham, na época clássica, tipos de educação sensivelmente diferenciados. Mas nos primeiros tempos isso não acontecia. Nos primórdios, a educação tinha por finalidade a preparação do cidadão para a defesa do seu país. Era por isso, de início, um ensino apenas militar, que incluía evidentemente os exercícios físicos. Pretendia adestrar no manejo das armas os futuros defensores da pólis.

Aparecida a pólis por meados do século VIII a.C., tal sistema explica-se perfeitamente por razóes históricas, com a ajuda das condiçôes geográficas do solo e de factores económicos. Com o declínio micénico no século XII a.C. e a longa movimentaçáo populacional que se lhe seguiu, acompanhada de intensas lutas, a ausência de um poder centralizado forte leva os habitantes a protegerem-se e a acolherem-se em pequenas comunidades, no cimo de colinas que rodeavam de muralhas e a que davam o nome de acrópole. A partir de determinada altura, para melhor resistirem aos ataques constantes, essas pequenas comunidades agrupam-se em unidades mais amplas, através de sinecismo e contribuem, desse modo, para a formação das póleis que se fecharam sempre num individualismo orgulhoso, sem nunca atingirem uma unidade política. ${ }^{1}$

1 Apesar de várias tentativas e passos nesse sentido, o particularismo foi sempre mais forte. Ora isso é que já se torna mais difícil de perceber — a manutenção de tal sistema por vários 
De espírito particularista, o Grego considerava a pólis a única base possível de uma existência civilizada e livre. ${ }^{2}$ Mesmo quando faziam alianças, como é o caso das simaquias, os seus membros eram considerados Estados soberanos. Foi esse particularismo que os envolveu em conflitos constantes, pelo que as cidades-estado gregas passaram o tempo da sua história, quase na totalidade, desavindas e em luta. ${ }^{3}$

É natural portanto que, nos primeiros tempos, a excelência do homem - a aretê — fosse o ideal heróico, a coragem e destreza no combate e que, em consonância com isso, nos primeiros séculos da existência da pólis, a educação do jovem fosse essencialmente militar e visasse a aprendizagem directa ou indirecta do manejo das armas. Neste domínio, Esparta sobressai desde cedo. Fora das primeiras, senão a primeira, a introduzir a hoplitia, nos fins do século VIII ou inícios do VII a.C., em detrimento

séculos até que, anémico, se vai diluir aos poucos ao longo do séc. IV a.C. Sobre a pólis e significado de tal sistema, vide EHrEnberG (1960) 88-192.

${ }^{2}$ Um facto acentuado com vigor por Platão e Aristóteles. O primeiro toma a pólis como modelo do seu Estado ideal, o segundo ocupa-se do assunto no livro I da Política. Por dois elucidativos passos de Platáo, (Criton 50a sqq. e Leis I, 625e), vemos quanto a pólis era apaixonadamente sentida. Vide Ferreira (1992a) 96-103 e (1992), cap. 1.

${ }^{3}$ Uma vez declarada a guerra, tudo o que podia aproximar os Gregos era esquecido, os ditames da justiça são abolidos e contra o inimigo todos os meios se utilizam (cf. Tucídides 5. 84-116, sobretudo 89, 91, 105; Plutarco, Moralia 210e e 233b). Suspensos com a guerra leis e costumes, cometem-se violências de toda a espécie e as mais bárbaras atrocidades. Por ser uma das características mais evidentes e conhecidas da história grega, não interessa aqui repisar o assunto. 
da cavalaria. ${ }^{4}$ Tornou-se uma potência militar temida e respeitada e granjeou grande prestígio. $\mathrm{Na}$ sua cultura o ideal militar ocupava papel dominante.

$\mathrm{Na}$ poesia da época arcaica - cujas datas de início e final é costume situar entre 776 e em 480 a.C., respectivamente a data tradicional dos primeiros Jogos Olímpicos e o ano da batalha de Salamina - aliás na sequência do que se passava nos Poemas Homéricos (Il. 6. 208; 9. 443), amiúde é proclamado o ideal de praticar nobres feitos em defesa do país como objectivo máximo do jovem e do cidadáo pela poesia da época arcaica que vive em ligação estreita com a pólis. Encontramos a cada passo a ideia de que a guerra é a actividade nobre, de que é nos campos de batalha que o cidadão alcança a glória e de que a sua aretê reside na coragem em combate. São exemplos elucidativos Calino, um poeta de Éfeso, do séc. VII a.C., e Tirteu, poeta espartano do mesmo século, para dar um exemplo da área iónica e outro da dórica.

\section{..... É honra e glória para um homem combater pela pátria, pelos filhos e pela legítima esposa, contra o inimigo. ${ }^{5}$}

Exorta Calino (fr. 1 West, vv. 6-7) os seus concidadáos a pegarem em armas e a manterem-se firmes na frente de batalha.

${ }^{4}$ Sobre o aparecimento da hoplitia na Grécia vide ANDREwES (1974) 31-33; WebSTER (1958) 214-215; Snodgrass(1965) 110; Detienne (1968) 119-142.

5 Tradução de Rocha Pereira (2005) 119. 
Tirteu, por sua vez, compunha poemas de incitamento ao combate, entoados pelos soldados espartanos quando se dirigiam para a batalha (cf. Ateneu 14. 630e), nos quais o poeta póe em relevo o heroísmo e a valentia guerreira (fr. 10 WEST) e exorta os cidadãos a manterem-se firmes nas primeiras filas, pois essa é a verdadeira superioridade (fr. 12 WEST, vv. 1-9):

Eu não lembraria nem celebraria um homem pela sua excelência (aretê) na corrida ou na luta, nem que tivesse dos Ciclopes a estatura e a força e vencesse na corrida o trácio Bóreas, nem que tivesse figura mais graciosa que Titono, ou fosse mais rico do que Midas e Ciniras, ou mais poderoso que Pélops, filho de Tântalo, ou tivesse a eloquência dulcissima de Adrasto ou possuisse toda a glória - se lhe faltasse a coragem [valorosa. ${ }^{6}$

Mas nessa época, a par da guerra e da preparação para ela, deparamos com uma cultura que lentamente evoluía e se afirmava. Os nobres, além de se dedicarem a actividades relacionadas com o governo e defesa da pólis, levavam uma vida de requinte, apreciavam a arte, a poesia e a música e entregavam-se aos exercícios físicos. Neste domínio Esparta não se distinguia das outras, a não ser por se ter sobressaído em relação às demais nesses primeiros tempos. Do século VIII aos inícios do VI a.C. Esparta era um grande centro de cultura. Era na opinião de Marrou (1965: 46) a metrópole da

${ }^{6}$ Tradução de Rocha Pereira (2005) 121. 
civilização helénica e não apresenta de modo algum a imagem tradicional de cidade severa, guerreira e desconfiada que possuirá na época clássica. Sobressaiu naturalmente no domínio da preparação atlética, com inovaçóes a nível dos métodos de treino e da prática desportiva e com uma série significativa de vitórias olímpicas. ${ }^{7}$ Mas foi também cultora da poesia (Tirteu e Álcman) e da música, com duas escolas que exerceram alguma influência no século VII a.C. - a de Terpandro e uma outra a que estão ligados nomes como Taletas de Gortina, Xenódamo de Citera, Sacadas de Argos. Segundo Marrou (1965: 49), colocada no centro da cultura grega, a música assegura a ligação dos diversos aspectos da formaçáo do jovem: pela dança associa-se à ginástica e pelo canto veicula a poesia. Todos estes aspectos confluíam nas grandes manifestaçôes colectivas das festas religiosas, com procissóes solenes, competiçóes várias - atléticas, musicais, entre outras.

MasnoséculoVIIa.C., as diversas póleisgregas passam por crises sociais graves que as marcarão profundamente e que cada uma resolverá de maneira distinta. Nelas um grupo de cidadãos, ora restrito, ora mais alargado, bate-se com as realidades materiais e sociais que vai encontrando e transforma-as. Cada cidade-estado evoluciona mais ou menos significativamente, em luta com as dificuldades, os condicionalismos e as oposiçóes que encontra, até nos oferecer o quadro característico da época clássica.

${ }^{7}$ Refere Marrou (1965) 48-49 que entre 720 e 576, de 81 vencedores conhecidos, 46 são espartanos. Segundo Tucídides 1. 6, foram eles que introduziram na prática desportiva a nudez total do atleta e a aplicação de óleo no corpo. 
Em todas as póleis surge um núcleo comum de instituições, com funçôes idênticas de início em todas elas: a Assembleia do povo, o Conselho e os Magistrados, a que tinham acesso e neles participavam activamente apenas os cidadãos. ${ }^{8}$

O conflito entre os nobres detentores de todos os poderes na época arcaica - religioso, político,

${ }^{8}$ Os vários órgãos institucionais podem tomar nomes diferentes conforme a pólis. Assim, para dar o exemplo das duas mais poderosas cidades gregas do século V a. C., Atenas e Esparta, temos respectivamente Ecclesia (Assembleia) e Apela, para a Assembleia; Areópago e Gerusia, para o Conselho; e Arcontes e Éforos, para os Magistrados.

Numericamente a soberania dos cidadáos era a de uma minoria, tanto nas oligarquias como nas democracias. Apesar da falibilidade e insegurança das cifras e estatísticas para essa época, tudo indica que o seu número náo teria ultrapassado os quinze por cento da totalidade da população, mesmo nas democracias mais evoluídas e abertas, como é o caso de Atenas. A população de uma pólis era constituída por pessoas livres e não-livres. Eram livres os cidadãos e os estrangeiros com autorização de residência, cujo nome mais usual é o de metecos. Entre as não livres incluem-se os habitantes que estão submetidos a qualquer grau de dependência e não podem dispor da sua pessoa: desde os considerados animais ou coisas os escravos mercadoria, algo que se compra e se vende - até aos que, obrigados a trabalhar a terra de outrem, os servos, tinham de entregar uma parte do produto e, de acordo com o estatuto, estavam numa situaçáo melhor do que a dos anteriores.

Note-se que uma coisa é o estatuto e outra a situação real. Pode acontecer que numa pólis os não livres possuam um estatuto mais benéfico do que os de outra, mas se encontrem numa situação real inversa. É o que se passa com Atenas e Esparta: na primeira, os escravos, embora estatutariamente considerados uma mercadoria, têm uma situação real incomparavelmente melhor do que os hilotas de Esparta que pelo estatuto sáo servos.

Em Atenas, de autor para autor, a variabilidade no número de habitantes ultrapassa com frequência os cinquenta por cento. Vide Ferreira (1990) 181-184. 
económico, jurídico - e um leque bastante diversificado económica e socialmente, que, apesar de cidadãos, se encontravam numa situação subalterna e não gozavam de quaisquer direitos políticos, a não ser participar nas reuniōes da Assembleia, cujo poder era entâo na prática nulo. $\mathrm{O}$ conflito conhece momentos graves nos séculos a. C. VII e VI que as póleis, numa primeira fase, de modo geral tentam resolver pela nomeação dos legisladores - homens íntegros que, com a confiança das várias facçóes, eram escolhidos por mútuo acordo para tomarem as medidas necessárias para resolverem a crise - com a missão de procederem a uma série de reformas e dotar as cidades de códigos de leis; essas medidas não conseguem solucionar os confrontos e as lutas levam às tiranias que, além de centralizar os diversos poderes ainda de posse dos nobres, contribuirá para o nivelamento social; ao serem expulsos os tiranos, instauram-se ora oligarquias - tenham elas por base o nascimento, a riqueza ou os dois - ora democracias, mais ou menos evoluídas. Mas, ao desaparecerem as tiranias, qualquer que seja o regime instaurado, as póleis que elas deixam já não são as mesmas. Os poderes não estavam nas mãos dos aristocratas, mas centralizados nas diversas instituiçóes que passam daí em diante, quer se trate de uma oligarquia, quer de uma democracia, a dirigir a pólis.

Ora nessa evolução Esparta parece trilhar um caminho diferente do da maioria das outras cidades, em especial do de Atenas. A partir de fins do século VII 
a.C., possivelmente em consequência de lutas sociais subsequentes à Segunda Guerra Messénica (c. 650-620 a.C.), a cidade da Lacónia passa a valorizar a parte física e militar da sua formação, em detrimento da intelectual. Tudo parece indicar que a aristocracia, talvez chefiada por Quílon, póe termo à agitação popular e estabiliza o seu triunfo por meio de instituiçóes apropriadas - as reformas que a tradição transmitiu sob o nome de Licurgo. ${ }^{9}$ A cidade começa a enquistar-se, fechase e perde vitalidade cultural. Erige em ideal máximo a defesa da pólis e centra a sua atenção na actividade militar, a que sujeitava toda a vida do cidadáo, desde os mais tenros anos. Esparta é um caso paradigmático de empenho na preparação do jovem para a guerra. Essa pólis era uma máquina de combate: vivia para ele e em função dele. Verdadeira cidade-quartel, as suas instituiçóes haviam sido pensadas e dispostas para que os cidadãos estivessem sempre preparados e prontos a entrarem em combate. $\mathrm{O}$ tipo de educação instituído tinha o nome técnico de agogê. Organizada em função das necessidades da pólis, toda ela estava nas máos do Estado.

Como é sobejamente conhecido, na Lacedemónia as crianças pertencem, desde que nascem, ao Estado - que eliminava as que fossem deficientes ou não apresentassem a robustez requerida (Plutarco, Licurgo 16) - e, a partir dos sete anos, passavam à posse do Estado e até à morte pertencem-lhe por inteiro. Sáo

${ }^{9}$ Sobre a figura de Licurgo e sua historicidade vide Ferreira (1992b) 64-65. 
então educadas pela pólis que lhes dava uma preparação fundamentalmente de índole física, ao ar livre, e toda ela virada para a intervenção na guerra. A educação propriamente dita dura até aos vinte anos. De cabelo cortado rente, ligeiramente vestidos, pés descalços, obrigados a dormir sobre uma esteira de canas (cf. Xenofonte, Lac. 2. 3-4; Plutarco, Lic. 16), sujeitos a uma vida parca e austera, os jovens espartanos, proibidos de se dedicarem a trabalhos manuais, viviam em comum, divididos em grupos, segundo as idades, dirigidos pelo mais avisado de cada um desses corpos, e aprendiam a obedecer e a suportar a fadiga e a dor (cf. Platáo, Leis 1, 633b-c), a falar de forma concisa e sentenciosa, ou seja a serem lacónicos. ${ }^{10}$ Trata-se de uma educação colectiva que retira a criança aos pais para o fazer viver numa comunidade de jovens. Segundo Marrou (1965: 53), essa educação compreendia treze anos, agrupados em três ciclos: dos 7 aos 11 anos; dos 12 aos 15; e dos 16 aos 20, a época da efebia — ou a época em que o jovem era eiren, para usar o modo de a designar em Esparta. A finalidade desta educação era fazer deles soldados, pelo que tudo era sacrificado a esse fim único. Dava-se primazia aos exercícios físicos com o objectivo apenas de desenvolver a força do corpo, a que se juntava a aprendizagem directa do ofício de soldado: exercícios

${ }^{10}$ Xenofonte, República dos Lacedemónios 2. 1-11 e 6. 1-2; Plutarco, Licurgo 16-20.

O laconismo era uma característica tấo cultivada pelos Espartanos - os habitantes da Lacónia — que passou à posteridade como um substantivo comum para designar a qualidade ou defeito do que é parco em palavras. Plutarco, Licurgo 19-20 dá numerosos exemplos dessas sentenças concisas dos Lacedemónios. 
de treino com armas e de táctica de formação. Embora se não possa afirmar, como nota Marrou (1965: 54-55), que os Espartanos fossem de todo iletrados, o aspecto intelectual da sua educação estava reduzido a pouca coisa - a ponto de os Dissoi logoi 11. 10 afirmarem, com algum exagero, que os Lacedemónios consideram bom que os jovens não aprendam música nem letras.

Só quem receber este tipo de educação, tem as condiçóes necessárias para o exercício dos direitos cívicos (cf. Xenofonte, Lac. 10. 7; Plutarco, Inst. Lac. 238F 21)

Também as jovens tinham uma educação ao ar livre, em que o exercício físico predominava. Música e dança, ao contrário do que acontecia na época arcaica, ficavam em segundo plano (Xenofonte, Lac. 1. 4). Esparta queria fazer delas mães robustas que pudessem dar à pólis futuros cidadãos robustos. ${ }^{11}$ Trata-se afinal de uma política de eugenismo (cf. Plutarco, Licurgo 14. $3)$.

Aos vinte anos, atingido o termo da sua formação e a idade adulta — ou seja ao tornar-se sphaireus "que jogava a bola" - o Estado continuava a impor as suas exigências. Com uma vida familiar muito limitada, os Espartanos continuavam a viver em grupos, tal como combatiam, obrigados a tomarem uma refeiçâo diária em comum nos chamados syssitia, e eram sujeitos a preparação física e a treino militar constantes, de modo a encontrarem-se sempre prontos a entrarem em

${ }^{11}$ Cf. Xenofonte, República dos Lacedemónios 1.3 sqq.; Platáo, Leis 7, 804d e 813e; Plutarco, Licurgo 14-15. 
combate. Observa Plutarco, Licurgo 25 que os cidadãos foram acostumados «a não quererem, a não saberem mesmo viver sós, a estarem sempre unidos, como as abelhas, em proveito do bem público à volta dos seus chefes. Desse modo se procurava, acima de tudo, incutir o sentido comunitário e o espírito de disciplina, a ponto de a obediência ser considerada a virtude fundamental e quase única, na qual o jovem era industriado desde a mais tenra idade.

A educação espartana - que era supervisionada por um magistrado especial, o paidónomo, verdadeiro ministro da educação, e, desde a Antiguidade, tem despertado entusiasmo em muitos ${ }^{12}$ — dava tanta importância ao aspecto moral como à preparação técnica do soldado. Trata-se de uma educação toda ela ordenada a incutir no jovem o ideal de patriotismo e devoção à pólis até à morte. $\mathrm{O}$ resultado dessa educação está bem expresso no episódio do sacrifício de Pelópidas e seus homens nas Termópilas que motivou as belas palavras de Simónides (fr. 5 Diehl):

Dos que morreram nas Termópilas, glorioso é o destino, bela a morte.

É seu túmulo um altar; em vez de gemidos, a sua lembrança; o pranto se volve em elogio.

Esta pedra tumular

não a destruirá o bolor, nem o tempo que tudo vence. Esta sepultura de homens corajosos escolheu para a

Iguardar

${ }^{12}$ Vide Ollier (1932-1943). 
a fama excelsa da Grécia. Testemunha-o Leónidas, rei de Esparta, que deixou o ornamento de uma grande [valentia e um renome imperecivel. ${ }^{13}$

A morte física transformou-se em vida moral: os que agora jazem não são mortos. Como refere H. Fränkel, foram elevados à categoria de heróis protectores, como os mortos dos tempos míticos cujos túmulos eram ao mesmo tempo santuário. ${ }^{14}$

A educaçáo procurava incutir como norma do bem o interesse da pólis e de que é justo o que serve para o seu engrandecimento. Aplicado este princípio às relaçóes com os outros estados, conduz ao uso da astúcia e da fraude. Por essa razão há o cuidado de treinar os jovens na dissimulação, na mentira, no roubo (cf. Xenofonte, Lac. 2. 6-8; Plutarco, Licurgo 17-18): desse modo mal alimentado, o jovem era abandonado nas regióes desabitadas e convidado a roubar para completar a sua ração (cf. Xenofonte, Lac. 2. 5-8; Plutarco, Licurgo 17). Só não devia ser apanhado ou descoberto.

Esparta considerava todas as outras actividades estranhas à guerra - agrícolas, comerciais, industriais ou artesanais - indignas de homens livres; para essa pólis apenas a guerra, e a sua consequente preparaçáo, prestigiava e dignificava os cidadãos. Por isso proibia estes, os "Pares" (Homoioi), de se dedicarem a qualquer outra ocupação. ${ }^{15}$

${ }^{13}$ Tradução de Rocha Pereira (2005) 177.

14 ( $\left.{ }^{3} 1969\right)$ 365-366.

15 Para a proibição de os cidadãos espartanos se dedicarem a 
Mas nas outras póleis, de modo especial a Atenas, a formação não se centrou exclusivamente no treino físico e na preparação militar, mas evoluiu para um sistema educativo que visava o desenvolvimento harmónico das faculdades. Vou tomar Atenas por modelo, por ter sido aí que tal equilíbrio primeiro se verifica, no século VI a.C. ${ }^{16}$

Combater em defesa da pólis continuou a ser o principal meio de alcançar a glória, mas não era, como se tornou em Esparta, uma preocupação obsessiva. Escreve Tucídides (1.6) que nos primeiros tempos, por não existirem casas protegidas e comunicaçóes seguras, os Gregos tinham o hábito de andarem armados e que Atenas foi a primeira cidade a abandoná-las (1. 6.3):

Os Atenienses foram os primeiros entre eles a abandonarem as armas de ferro e, sem constrangimento, entregaram-se a uma vida mais civilizada.

Nas provas atléticas encontravam os Gregos, sobretudo os da classe nobre, um campo para mostrar a sua superioridade e excelência. Eram famosos os Jogos Olímpicos, os Píticos, os Nemeus e os Ístmicos — realizados em Olímpia, Delfos, Nemeia e Istmo de Corinto, respectivamente - e constituía uma grande glória ser proclamado vencedor numa das suas provas,

actividades económicas cf. Xenofonte, República dos Lacedemónios 7; Plutarco, Licurgo 23. 2-3.

${ }^{16}$ Para a educação na época arcaica e sua evoluçáo vide Marrou (1965) 74-86; Rocha Pereira (2003) 367-380. 
sobretudo as dos Jogos Olímpicos que, segundo a data tradicional, teriam começado em 776 a.C.

Ora na preparação, quer para o combate, quer para os Jogos, o exercício físico torna-se essencial. Daí que o ensino da ginástica comece por preponderar e que o mestre de educação física - o paidotriba, como lhe chamam os Gregos - seja o primeiro a aparecer. Existente já talvez no século VII a.C., as lições eram dadas na palestra ou no ginásio, sem me deter aqui na discussão sobre a diferença e relação que possa existir entre os dois. ${ }^{17}$

Mas como se deduz de um passo célebre da Ilíada (9. 443), Fénix ensinara Aquiles também a fazer discursos e não apenas a praticar nobres feitos. Ora com a afirmação da pólis ou cidade-estado ao longo da época arcaica — ou seja no decurso dos séculos VIII a VI a.C. - a necessidade de intervir no Conselho e na Assembleia, um órgão colegial o primeiro e constituído por todos os cidadãos a segunda, obriga o dirigente a ter de usar da palavra e a saber convencer os seus concidadáos.

Assim aparece o ensino da música, através do citarista, o mestre que, talvez a partir do século VI a.C., ensinava as crianças a tocar cítara, e o das primeiras letras, a cargo do gramatista que ensinava a ler e a escrever e cuja existência parece datar dos inícios do século $\mathrm{V}$ a.C.

${ }_{17}$ Discute-se se o ginásio era para os mais velhos e a palestra para os mais novos, se esta era uma parte daquele e se o primeiro era público e a segunda particular. Vide Delorme (1960) e Rocha Pereira (2003) 368 nota 2. 
O ensino dos três mestres tinha grande difusão como se pode deduzir de várias afirmaçōes e alusôes dos autores antigos. Em Aristófanes, o salsicheiro Agorácrito dos Cavaleiros, embora saiba ler, não frequentou o mestre de música nem o de ginástica (vv. 1235-1293) e nas Vespas, num diálogo entre Filocléon e Bdelicléon, o não saber tocar cítara equivale a ignorância (vv. 959 e 989). Platão, no Protágoras 325c-326e, fala da importância desses três mestres na educação e acentua que os grammatistoi, depois de as crianças aprenderem as letras, os números e compreenderem o que se escreve (325e-326a)

póem-nas a ler nas bancadas as obras dos grandes poetas, e obrigam-nas a decorar esses poemas, nos quais se encontram muitas exortaçôes, e também muitas digressóes, elogios e encómios da valentia dos antigos, a fim de que a criança se encha de emulação, os imite e se esforce por ser igual a eles.

No que respeita aos mestres de música e de ginástica, refere que procedem de modo idêntico e, depois de os jovens saberem tocar, fazem-nos aprender as obras dos grandes poetas líricos e desse modo (326b326c)

obrigam os ritmos e harmonias a penetrar na alma das crianças, de molde a civilizá-las, e, tornando-as mais sensiveis ao ritmo è harmonia, adestram-nas na palavra e na acçáo. Na verdade toda a vida 
humana carece de ritmo e de harmonia. Além disso, ainda se mandam

as crianças ao pedotriba, a fim de possuirem melhores condiçöes físicas, para poderem servir a um espirito são, e não serem forçadas à cobardia, por fraqueza corpórea, quer na guerra, quer noutras actividades. ${ }^{18}$

Este texto de Platão, além de chamar a atenção para o equilíbrio que deve existir entre a preparação física e a formação espiritual — há uma mútua influência e de elucidar que essas escolas eram particulares, vinca o valor formativo da poesia e da música.

Os Gregos davam grande importância ao ensino destas duas artes que então não estavam tão separadas como hoje. Lembremos que parte da poesia, sobretudo a lírica, destinava-se a ser cantada e que não havia distinção entre o poeta e o músico. Junto do citarista e do gramatista, os jovens aprendiam a cantar e a recitar as obras dos grandes autores, algumas delas de cor. Temos notícias de que os Poemas Homéricos e obras de Sólon eram aprendidos nas escolas. ${ }^{19} \mathrm{O}$ jovem Nicérato, no Banquete de Xenofonte declara saber os Poemas Homéricos de cor, por o pai lhos ter mandado fixar em pequeno para fazer dele um homem de bem - um agathós (3. 5. 6). Pretendia-se fazer penetrar na alma da criança a harmonia e o ritmo e fornecer-lhe modelos que nela despertassem a emulação. Ésquines, um orador do século IV a.C., exalta o valor educativo dos modelos

18 Tradução de Rocha Pereira (2005) 422.

${ }^{19}$ Cf. Xenófanes, fr. 10 Diels (Homero); Platão, Timeu 21b (Sólon). 
(Contra Ctesifonte 246), e muitos são os casos de imitação ou emulação. Refiro apenas Alexandre Magno, que com a Ilíada à cabeceira, tinha por paradigma Aquiles, mas se lamentava de náo ter, como aquele herói, um outro Homero que cantasse as suas façanhas. É afinal a afirmação do valor psicagógico da poesia e da música. Estamos perante a educação pelo paradigma de que falava Platão e que tinha tanta importância na formação dos jovens na Grécia antiga. Já a encontramos em acção nos Poemas Homéricos, quando Atena aponta a Telémaco o exemplo de Orestes para o motivar a ir colher informaçóes sobre o pai. ${ }^{20} \mathrm{E}$ com ela deparamos ao longo das épocas posteriores até ao nosso tempo. Um caso curioso é o que se passa com os Revolucionários Franceses que procuraram imitar os modelos da Grécia e de Roma. O Padre Grégoire encaminha-nos nessa direcção, ao referir que há tendência a imitar as grandes figuras do passado e ao aconselhar que se semeie virtude para recolher virtudes, já que, se a reputação de Milcíades inflamou o coração de Temístocles e o tornou seu émulo, um sofisma desorienta e um mau exemplo arrasta. $^{21}$

Grande partedos homens da Revoluçãoencontravam esses paradigmas, de preferência, nos biografados de Plutarco e acima de todos eles estava Licurgo, o lendário legislador a

${ }^{20}$ Depois os próprios heróis homéricos foram tomados como modelos pelos Gregos dos tempos futuros. JAEGER (1954) cap. 3 (trad. port. pp. 56-77); Ehrenberg (1964) 10-12; Marrou (1965) cap. 1; GRIFFIN (1977) 39-53.

${ }^{21}$ Afirmaçóes de um discurso proferido na Convenção Nacional em 28 de Setembro de 1793. Cf. Oeuvres de l'Abbé Grégoire, ed. par A. Soboul (Liechenstein, 1977) 59-60 (citação da p. 59). 
quem a tradição atribuía a criação da Esparta clássica. Mas, se Licurgo é o modelo dessa virtude entre os Helenos, Marco Bruto e Catão de Útica são-no entre os Romanos, com predominância para Bruto. ${ }^{22}$

Mas esta formação, além de se fazer em escolas particulares que, como o afirmava Platáo no texto do Protágoras acima citado, apenas estavam ao alcance dos mais ricos, dizia respeito aos rudimentos e terminava na adolescência. Mesmo no século V a.C., como observa Marrou (1965: 77), essa educação continuou mais orientada para a vida nobre, a do grande proprietário rico, e menos para o ateniense médio que ganha a vida como camponês, artesão ou no pequeno comércio.

Paralelamente a essa formação básica e depois de ela terminar, a grande escola era o convívio social que tem significativa importância educativa em Atenas, com particular saliência para o convívio na Ágora, nos banquetes, nos ginásios. Estes, frequentados pelos jovens para os seus treinos e exercícios de ginástica eram procurados por muitos que, além de admirarem a beleza e agilidade dos mais novos, com eles conviviam e davam-lhes conselhos. A darmos crédito a Platão e Xenofonte, Sócrates procurava com frequência esse local para ensinar. ${ }^{23}$

${ }^{22}$ Assim Cheviner acentua que a vida austera desse indefectível defensor da República romana oferecia o modelo da virtude. Cf. Moniteur de 5 de janeiro de 1795.

${ }^{23}$ Alguns dos diálogos de Platão - caso de Laques, Lisis, Cármides - passam-se no ginásio. Isso tem o seu significado, mesmo que se admita alguma idealização do filósofo. 
A educação referida até aqui diz respeito apenas uma formação inicial ou básica. Depois passa a derivar sobretudo do convívio.

A poesia tem papel de relevo na formação do homem. Procura incutir nele o ideal heróico e incitá-lo a combater pela sua pólis, tanto na elegia guerreira já referimos Calino e Tirteu —, como na lírica coral (Simónides, Píndaro); procura incitá-lo a agir com justiça e com moderação (Sólon. Píndaro, Teógnis). ${ }^{24}$ Do que se acaba de referir se deduz que a poesia tinha um papel didáctico. Destina-se a ser cantada ou recitada e pressupunha um auditório, a quem o poeta quer transmitir a sua experiência ou exortar a determinada actuação: Hesíodo, ao irmão; Calino, Tirteu, Sólon, aos concidadãos; Teógnis, ao seu jovem amigo Cirno. Vejamos um texto deste último (vv. 27-30):

Por ser teu amigo, ó Cirno, é que te vou dar estas normas, Lque eu mesmo sendo criança, aprendi com homens de bem.

Sê sensato, não busques honras, mérito, abastança, em actos vergonhosos ou injustos. ${ }^{25}$

Teógnis — não vou aqui discutir a questão da autenticidade da maioria dos versos da sua colectânea ${ }^{26}$ - continua a dar conselhos práticos sobre a vida e

${ }^{24}$ Mesmo um poeta como Arquíloco que sobressai pelo individualismo, rejeita a glória homérica e prefere o senso comum de salvar a vida em caso de perigo (fr. $6 \mathrm{~d}$ ), mesmo ele era recitado em concursos (Heraclito, fr. 42 Diels).

25 Traduçáo de Rocha Pereira(2005) 167.

${ }^{26}$ Sobre o assunto, vide Rocha Pereira (2003) 207-208. 
a transmitir-lhe os conhecimentos que ele próprio aprendera de outro. Temos aqui um exemplo da transmissão viva do saber de geração em geração: um homem feito a ensinar um jovem. Processo característico da mentalidade grega, encontramo-lo já nos primórdios da cultura helénica, na Ilíada, no caso de Fénix e Aquiles. É também o caso da relação de Sócrates com os discípulos. É evidente e natural que nesta transmissão da experiência própria se imiscua o elemento subjectivo (caso de Arquíloco, Mimnermo).

Transmitida de mais idoso a jovem, cantada em festividades e concursos, aprendidos nas escolas, por vezes até de cor, a poesia tornou-se um poderoso veículo de formação, mas também de transmissão do saber. Recorde-se que as Musas eram consideradas filhas de Zeus e de Mnemósine, a memória.

A Ágora era um importante centro cívico, religioso e comercial, e as condiçóes especiais do clima na Grécia permitia ou convidava à vida ao ar livre. $\mathrm{Na}$ ágora ficavam vários templos, altares estátuas e edifícios públicos de grande importância religiosa, política e social; nela se realizavam as sessôes da Assembleia (Ecclesia), antes de ser transferida no século $\mathrm{V}$ a.C. para a colina da Pnix, e as reunióes do Conselho dos Quinhentos, ou Boulê (no Buleutérion), dos tribunais da Helieia; se encontrava o Pritaneu - ou Tholos - em que os prítanes se reuniam e viviam permanentemente; num dos seus pórticos, a stoa basileios, exercia o seu magistério o arconte-rei julgar os casos relacionados com a religião e impiedade - e num outro e no Pritaneu se encontravam gravados 
em pedra diversos documentos. Como o código de Sólon; aí, separado por um pórtico central, decorria diariamente o mercado. Era, portanto, a ágora um local de grande afluência, que os Atenienses procuravam para conversar e discutir sobre diversos assuntos.

O symposion - que de modo geral se traduz, talvez indevidamente, por banquete — tinha um significado social e cultural de grande importância. Os Gregos - evidentemente os que tinham posses para isso - gostavam de se reunir em festins em que se comia e bebia, mas sobretudo se convivia, conversava, discutia, por vezes assuntos elevados, e se entoavam poemas (os skolia) de grandes autores, como Alceu (cf. Heródoto 6. 129; Aristófanes, Nuvens 1353-1379). O symposion, além de aparecer representado em muitos vasos, motivou referências, foi tema e deu o título a obras de grandes autores gregos: por exemplo, Platão e Xenofonte. ${ }^{27} \mathrm{O}$ primeiro é um caso elucidativo: além de várias referências em que exalta o poder educativo do banquete, se bem dirigido (Leis 637b-642a, 652a-653a, 671a-672b), escreve uma obra com esse título em que várias figuras conhecidas e de relevo na Atenas de então — Sócrates, Aristófanes, Fedro, Pausânias, Alcibíades se reúnem em casa do tragediógrafo Ágaton para celebrar uma sua vitória nas Grandes Dionísias. ${ }^{28}$

O desejo de as famílias nobres conhecerem o seu passado e a ânsia de se ligarem a um herói da tradição

${ }^{27}$ Depois muitos outros trataram o tema, que o Renascimento volta a retomar.

28 Ágaton é considerado o quarto grande trágico, depois de Ésquilo, Sófocles e Eurípides. 
lendária faz aparecer as genealogias. A empresa da colonização, os contactos comerciais que esta motivou ou incentivou e as consequentes viagens de exploração das zonas costeiras originam os périplos que descrevem essas zonas e os relatos de fundaçôes de cidades. Tudo isso desperta a curiosidade pelas terras e lugares distantes e o desejo de conhecer novas regióes. Aparecem as mais antigas cartas geográficas gregas: o primeiro mapa é atribuído a Anaximandro, do século VI a.C. (Estrabão 1. 1. 11); Hecateu de Mileto (séc. VI-V a.C.) escreve uma Descrição da Terra que ilustra com um mapa. Heródoto compóe a sua obra - em que a geografia e a etnografia tem papel importante - depois de longas viagens em busca de informaçóes junto de outros povos.

Por seu lado a curiosidade ao mundo circundante e o acto de se admirar perante os seus fenómenos que, no dizer de Aristóteles (Metafísica 982b) constitui precisamente a base do filosofar, vai fazer aparecer os primeiros filósofos que buscam a origem das coisas e a constituiçáo de tudo quanto existe e procuram explicar os fenómenos naturais, sobretudo as revoluçóes dos astros e os eclipses. Esses filósofos pré-socráticos encontravam-se a cada passo ligados pela relação mestre/ discípulo e estavam integrados em escolas filosóficas que exerceram papel significativo na investigação da natureza e na busca do saber. Se náo temos a certeza da relação entre os três pensadores milésios - Tales, Anaximandro e Anaxímenes - e se hoje está posta de lado a existência aí de uma escola, a Escola Eleata, fundada por Parménides, e a Escola Pitagórica foram 
dois focos importantes de desenvolvimento e transmissão do saber. No domínio educativo interessa de modo especial a pitagórica com o seu ideal de vida que reveste a procura do saber com um carácter religioso. Pressupóe a superioridade intelectual em relação à física e admite a possibilidade de uma sobrevivência feliz no Além. Supõe M. H. Rocha Pereira que pertencerá a esta escola a doutrina exposta no mito da II Olímpica de Píndaro: quem conservar a alma afastada da injustiça durante três existências terá um lugar no Jardim das Delícias, sob a legislação de Radamanto e na companhia de heróis como Peleu, Cadmo, Aquiles..$^{29}$ Se assim for, como nota a mesma autora, a escola pitagórica abre perspectivas de imortalidade ao sábio que se vai purificando até se conseguir libertar do ciclo dos nascimentos.

A evolução da pólis ateniense no sentido da democracia tornou instituiçóes principais do regime a Assembleia, constituída por todos os cidadáos, o Conselho dos Quinhentos, ou Boulê, e a Helieia, para que eram escolhidos à sorte, respectivamente, cinquenta e seiscentos de cada uma das dez tribos. Possibilitou desse modo a participaçáo cada vez maior dos cidadãos, mas, tratando-se de órgãos colectivos, neles a arte de persuadir exercia grande importância. Dava por isso vantagens aos mais capazes e melhor apetrechados. O espírito de competição que naturalmente surgiu, que no domínio político, quer no judiciário, exigia uma preparação intelectual cada vez mais acentuada e fez surgir a necessidade de uma formação escolar para além da adolescência.

${ }^{29}$ (1955) 63-67. 
Vêm responder a essa exigência os sofistas, que, se não tiveram grande importância na história da filosofia - contributo apenas no domínio da epistemologia ${ }^{30}$ , exerceram papel de relevo na cultura e deixam marca indelével na história da educaçáo, a faceta que aqui nos interessa. Em tal domínio criam um currículo de estudos que podemos considerar o embrião das futuras sete artes liberais, o trivium e o quadrivium da Idade Média. ${ }^{31}$ Em parte herdado dos Pré-socráticos, em especial dos Pitagóricos, e em parte criado por si, esse currículo era constituído por disciplinas do foro literário (criação sua: gramática, dialéctica, retórica) e do domínio científico (herdado: geometria, aritmética, astronomia e música). Interessados nos problemas concretos do homem e nas relaçóes entre as pessoas, dominam as técnicas que permitem intervir nessas relaçóes pela discussão — ou seja pela dialéctica - e pela arte de persuadir, a retórica, e fazem-se mestres no ensino dessas técnicas. Não é de estranhar, portanto, que as suas principais inovações se situam no domínio dos estudos literários: desenvolvem muito a retórica — cujos fundamentos se devem a Córax e Tísias nos inícios do séc. V a.C. - e a dialéctica; criam a gramática (atribuída a Protágoras), crítica literária, prosa artística em ático; fazem estudos de sinonímia. Tudo matérias do domínio da arte de

${ }^{30}$ Vide Rocha Pereira (2003) 446 e n. 1.

Da vasta bibliografia sobre os Sofistas vide, entre outros, Guthrie (1971); Kerferd (1981a); Kerferd (1981b); Rocha Pereira (2003) 446-455. Para a tradução dos fragmentos vide Dumont (1969).

${ }^{31}$ Vide Rocha Pereira (2003) 449-451. 
bem falar e convencer, ou vencer pela argumentação, o opositor, quer como ser isolado, quer como membro do grupo social. Com um ensino itinerante, sem escola fixa, remunerado (e. g. Platão, Apologia 19e-20a; Isócrates, Antídosis 3), ${ }^{32}$ os sofistas erigiam o homem em alvo do seu pensamento:

O homem é a medida de todas as coisas, das que são, enquanto existem, e das que não são, enquanto não existem. $^{33}$

proclama Protágoras (fr. 1 Diels), o maior deles. A educação dos sofistas, completa, enciclopédica, pretendia formar os jovens com vista a uma futura intervenção na pólis, a fazer deles bons dirigentes — ou seja dotá-los uma technê politikê que lhes dará a aretê política. Daí que, embora centrado no homem, o seu pensamento não o vê como um ser isolado, mas como um elemento integrado na célula social que é a pólis, para desse modo prever as suas reacçóes em grupo, como membro da Assembleia e dos outros órgãos, e poder influir nas suas decisóes pela persuasão e argumentação — ou seja no seu ensino já se encontram os inícios da sociologia. Partidários da concepção filosófica da impossibilidade de aceder a outra verdade que não seja a da opinião, válida apenas para aquele que a professa e comunicável por persuasão, os sofistas defendiam que era possível persuadir do que quer que fosse e do seu contrário.

32 Sobre o escândalo que isso provocou e razóes do facto vide Rocha Pereira (2003) 448 e nota 7.

33 Tradução de Rocha Pereira (2005) 289. 
Os sofistas foram os primeiros professores e o seu ensino - que despertava considerável entusiasmo entre os jovens, como se depreende do Protágoras de Platão (310a-311e, 314b-315d) — vinha responder a uma necessidade profunda de Atenas que exigia um novo tipo de educação. A antiga educação aristocrática, baseada no conhecimento dos poetas antigos não correspondia às necessidades de uma pólis democrática. Pelo contrário, os sofistas estabeleceram um currículo de estudos e diziam-se detentores de um saber que eram capazes de comunicar aos ouvintes: um saber que lhes permitiria afrontar todas as questôes e realizar, por conseguinte, uma brilhante carreira política. O seu ensino, essencialmente pragmático, fornecia aos jovens discípulos as técnicas de argumentação e persuasão indispensáveis para se poderem impor na vida quotidiana, nos tribunais e na Assembleia. Mas, devido ao alto custo das liçôes, o acesso a esse ensino ficava restringido às classes sociais mais elevadas, em especial à aristocracia. Curioso paradoxo: os sofistas trazem a Atenas o tipo de educação necessária a um Estado democrático, mas a sua clientela reduz-se aos jovens provenientes dos meios mais abastados. Contribuem assim para acentuar o desequilíbrio social, já que colocavam nas mãos dos que possuíam mais recursos económicos uma técnica que lhes permitia persuadir e consequentemente dominar o dêmos. $^{34}$

${ }^{34}$ Temos informaçóes várias de que os sofistas se pagavam bem pelas suas liçóes: e. g. Platão, Apologia 20a; Laques 186c; Hipias Maior 282b-e; Górgias 519d; Ménon 91d; República 1, 337d; Isócrates, Contra os sofistas 3. Sobre as vantagens e desvantagens do 
De certo modo contemporaneamente ao sofistas, mas fundamentando a sua moram na razão, Sócrates dá também grande importância à educação. Aliás toda a sua vida - tanto quanto se pode deduzir dos testemunhos que dele nos chegaram (Aristófanes, Platão, Xenofonte, Aristóteles) — foi um permanente acto educativo. ${ }^{35}$ Pensava Sócrates que o útil se identifica com o bem e que existe uma lei superior que pode ser atingida pela razão e em todas as ocasiōes da vida deve ser seguida, como bem o demonstra no episódio narrado no Críton e no Fédon. Desse modo, o saber conduz à prática do bem e só a ignorância leva ao erro ou ao mau procedimento. Como o homem deve adequar a acção ao pensamento e colocar todo o empenho em manter uma alma recta esforço em que reside a virtude - é essencial a educação que desfaça a ignorância e permita agir correctamente. Daí concordar com W. Jaeger quando lhe chama o mais espantoso fenómeno educativo na história do ocidente. $^{36}$

No século IV a.C., três mestres trouxerem significativos contributos à história da educação: refirome a Isócrates, a Platão e a Aristóteles.

O primeiro funda uma escola que, situada na periferia da cidade, era muito frequentada e exerceu

ensino dos Sofistas vide Rocha Pereira(2003) 450-451.

35 Sobre esses testemunhos e as possíveis doutrinas de Sócrates vide Rocha Pereira (2003) 456-464.

36 (1954) 475-476. 
grande influência na Atenas de então e no futuro. ${ }^{37}$ Apesar de o seu ensino ser remunerado, os alunos afluíam em grande número (Antídosis 41 e 87), mas não aceitava muitos ao mesmo tempo: de modo geral não mais de nove ou dez, já que os grupos pequenos, além de proporcionarem o convívio, não dispersavam a atenção. O curso, que durava três ou quatro anos (Antídosis 87), privilegiava os estudos literários e pretendia fornecer uma vasta cultura, em contacto com as obras dos bons autores, pelo que é considerado o pai do humanismo.

O seu magistério - que ele defende no discurso Antídosis, já do fim da vida - era uma espécie de ensino superior que visava uma formação política e procurava habilitar os discípulos a exercer papel relevante na pólis. O seu ensino que obteve grande aceitação na época e exerceu uma influência duradoira, deu frutos visíveis: Hiperides, Iseu e Licurgo, três grandes oradores do século IV a.C., foram seus discípulos.

Isócrates teve papel de relevo na história da educação: desenvolveu a parte literária do currículo dos sofistas. Pretendia ensinar a falar bem e considerava a retórica a arte suprema. Mas, ao contrário da dos sofistas, considerava que ela devia ter uma orientação ética. Em sua opiniāo (Panegírico 49)

${ }^{37}$ Sobre Isócrates e o seu papel na história da educação grega vide BECK (1964) caps. 7 e 8; JAEger (1954), cap. «Isócrates defende a sua paideia»; Marrou (1965) cap. 7; Rocha Pereira (2003) 481-484. 
os discursos belos e artísticos não são apanágio de pessoas inferiores, mas obra de uma alma que pensa bem ${ }^{38}$

e uma vida virtuosa dá autoridade ao orador (cf. Nícocles 3. 7).

Grande relevância no domínio da educação exerceu-a também Platão, não só pela escola que fundou e que se manteve activa por mais de oitocentos anos (é encerrada apenas no século VI da nossa era), mas também pelas propostas educativas que, embora sem grande audiência na sua época, vieram mais tarde a ser adoptadas, no período helenístico: refiro-me de modo especial à criação de escolas públicas e a uma educação das raparigas igual à dos rapazes (cf. Leis 805a). ${ }^{39}$

Feitas nos livros VII da República e das Leis, consagrados ao estabelecimento de um currículo de estudos, as suas propostas educativas não podem dissociar-se da sua teoria das ideias e da reminiscência ${ }^{40}$ e do pensamento de Sócrates, de quem foi discípulo e na boca do qual póe as suas doutrinas. Sócrates, no Ménon, interroga um escravo sobre geometria para provar que não faz mais do que lembrar o que ele já sabe. Desse modo a ciência é apenas reminiscência, como se vê também na alegoria da caverna da República 514a-518b. Considera a educação o primeiro dos bens,

38 Tradução de Rocha Pereira (2005) 331.

39 Sobre as propostas e plano educativos de Platão vide BECK (1964) cap. 5; Jaeger (1954) 541-550 e 712-866; Rocha Pereira (2003) 490-494 e Platão: a República (Lisboa, 1987), V-VII e XXVI-XXXIII.

${ }^{40}$ Sobre o assunto vide Rocha Pereira (2003) 488-490. 
que não deve ser desprezado (Leis 1, 644b). Exige uma aplicação desde a infância para desse modo alcançar a excelência - ou ser anêr agathós (Leis 1, 643b). Em face disso, o planeamento da educação deve estar a cargo do Estado, ou seja devem ser criadas as escolas públicas, e não deve diferençar a das raparigas da dos rapazes (Leis 7, 805a).

Nesse currículo de estudos podemos estabelecer três fases. A primeira, relativa à instrução inicial, segue a tradição dos três mestres: exercícios físicos, música e primeiras letras (Leis 7, 795d e 809e-810c). Na segunda fase, embora na República e nas Leis não haja unanimidade nas disciplinas propostas ${ }^{41}$ coincidem na necessidade do estudo da geometria, da aritmética e da astronomia, disciplinas preparatórias para a terceira fase dedicada à dialéctica, o método adequado à filosofia.

Trata-se, como se acaba de ver, de um currículo de pendor científico. Assim considera que ao estudo das letras deve o jovem dedicar apenas o tempo que o torne capaz de ler e de escrever. É que (Leis 7, 810b-c)

aprender composiçôes de poetas sem música, mas escritas, uma com metro, outras sem divisão rítmica, que são apenas escritas como se fala, e desprovidas de ritmo e harmonia, temos certas obras perigosas, que nos deixaram muitos homens dessa qualidade. ${ }^{42}$

${ }^{41}$ Por exemplo a República acrescenta às três disciplinas a seguir enumeradas a estereometria e a harmonia.

${ }^{42}$ Tradução de Rocha Pereira (2005) 434-435. 
É dada grande importância à matemática. Assim no Timeu aparece a noção de Deus como supremo geómetra e, à entrada da Academia, segundo a tradição, encontrava-se a inscrição "quem não souber geometria não entre».

Aristóteles foi ao mesmo tempo um grande filósofo e um grande cientista que marcou poderosamente o século IV a.C. e a posteridade. Para o nosso objectivo, interessa a escola que fundou, o Liceu, e os métodos de trabalho que lhe imprimiu - observação, investigação organizada, especialização, classificação e sistematização, e possivelmente experimentação, esporádica - e que naturalmente ele próprio utilizou. Criada em 335, essa escola chegou a compreender - pelo menos a partir de Teofrasto que lhe sucedeu na direcção — dois pórticos cobertos, um santuário dedicado às Musas, diversos outros edifícios onde existia uma biblioteca, colecçóes de animais e plantas, laboratórios, salas de conferência, possivelmente residências. Era uma verdadeira escola de ensino superior, ou melhor um centro de investigação. 


\section{Bibliografia}

Andrewes, A.: The Greek tyrants (London, 1956, reimpr. 1974).

Beck, F. A. G.: Greek education 450-350 B. C. (London, 1964).

Delorme, J.: Gymnasium. Étude sur les monuments consacrés à l'éducation en Grèce, des origines à l'empire romain (Paris, 1960).

Detienne, M.: "La phalange: problèmes etcontroverses", in J.-P. Vernant (ed.), Problèmes de la guerre en Grèce ancienne (Paris, 1968).

Dumont, J.-P.: Les sophistes. Fragments et témoignages (Paris, 1969).

Ehrenberg, V.: The Greek state (Oxford, 1960).

- Society and Civilization in Greece and Rome (Harvard, 1964).

Ferreira, José Ribeiro: A democracia na Grécia antiga (Coimbra, Livraria Minerva, 1990).

— Hélade e Helenos. 1- Génese e evolução de um conceito (Coimbra, 1992).

- A Grécia antiga. Sociedade e politica (Lisboa, 1992)

Fränkel, H.: Dichtung und Philosophie des frühen 
Griechentums (München, 1969³).

Griffin, J.: "The Epic Cycle and the Uniqueness of Homer”, JHS 97 (1977) 39-53.

Guthrie, W. K. C.: The Sophists, (Cambridge, 1971).

Jaeger, W.: Paideia I (Berlin, 1954³).

Kerferd, G. B.: The Sophistic movement (Cambridge, 1981a).

- (ed.): The Sophists and their legacy (Wiesbaden, 1981b).

Marrou, Henri-Irénée: Histoire de l'éducation dans l' Antiquité (Paris, 1965\%).

Ollier, F.: Le mariage spartiate. 2 vols. (Paris, 19321943).

Rocha Pereira, M. H.: Concepçóes helénicas de felicidade no Além, de Homero a Platão (Coimbra, 1955).

_Estudos de História da Cultura Clássica. I - Cultura Grega (Lisboa, 200399).

- Hélade. Antologia da Cultura Grega (Porto, $2005^{9}$ ).

SNOdgrass, A. M.: "The hoplite reform and history", JHS 85 (1965).

Webster, T. B. L.: From Mycenae to Homer (London, 1958). 